https://doi.org/10.52058/2786-4952 -2022-1(6)-487-498

Яцина Олена Федорівна доктор психологічних наук, доцент, професор кафедри наук про здоров'я, ДВНЗ «Ужгородський національний університет», пл. Народна, 3, м. Ужгород, 88000, https://orcid.org/0000-0003-0053-4814

\title{
ФЕНОМЕНОЛОГІЯ ІДЕНТИЧНОСТІ ТРАНСФЕСІОНАЛА
}

Анотація. Актуальність дослідження зумовлена зростаючими вимогами до підготовки особистості, здатної до безперервного оновлення своїх знань, швидкого переучування, розв'язування комплексних проблем, що уможливлюють успішне самоздійснення на межі різних професій. Метою роботи $є$ аналіз змісту і значення конструювання ідентичності трансфесіонала в процесі самореференції особистості. Дослідження феноменології ідентичності трансфесіонала відбувалося на основі синергетичної методології 3 використанням таких загальнонаукових методів дослідження як аналіз, синтез, порівняння та систематизація. У процесі наукової розвідки було виявлено особливості дослідження зв'язку освіти з трансфесією. Розглянуто питання перетворення професій в трансфесії як безперервний розвиток особистості, здатної виходити за межі базової професії і змінювати ії разом 3 собою. Обгрунтовано необхідність вивчення і можливості уточнення категорії «ідентичність» та «суб'єктність» у відповідності до мінливості і невизначеності умов соціальної реальності. У дослідженні представлено ідею самореференції ідентичності (професійної, транспрофесійної), що розглядається через характеристику операцій: самовизначення, самопізнання, самотворення, самовідтворення та самоздійснення, за допомогою яких відбувається розрізнення та описування ідентичності. Визначено, що самореференція як операціональна система дозволяє ідентичності у зміненій соціальній реальності самоздійснитись, вносячи свій смисл у власне життя. Відмічено, що трансфесіональність конструюється відповідно до актуальних життєвих інтенцій особистості й зазнає трансформацій синхронно до останніх. Практична цінність наукової роботи полягає у тому, що творення ідентичності трансфесіонала є відповіддю на запит щодо збагачення особистості знаннями і технологіями, які виходять за межі набутої професії i органічно співвідносяться із прагненням особистості до самоздійснення.

Ключові слова: транспрофесіоналізм, трансфесія, професійні навички, кваліфікаційні компетентності.

Yatsyna Olena Fedorivna Doctor of Psychological Sciences, Associate Professor, Professor of the Department of Health Sciences, Uzhhorod National University. Narodna Square, 3, Uzhhorod, 88000, https://orcid.org/0000-0003-0053-4814 
Журнал«Герспективитаінновації наукиљ

(Серія «Гедагогіка», Серія«ГЕихологія», Серія«Медицина»

№1(6) 2022

\section{PHENOMENOLOGY OF TRANSFESSIONAL IDENTITY}

Abstract. The relevance of the research is due to the growing requirements for training a person who can continuously update their knowledge, quickly retrain, and solve complex problems that make successful self-realization at the crossroads of various professions possible. The work aims to analyse the content and significance of constructing the identity of the transfessional in the process of self-reference of the individual. The research of the phenomenology of transfessional identity was carried out based on a synergetic methodology using such general scientific research methods as analysis, synthesis, comparison and systematization. In the process of scientific exploration, the peculiarities of the research have revealed the connection of education with transfession. The issues of transformation of professions into transfessions as a continuous development of a person who can go beyond the basic profession and change it with himself are considered. The necessity of studying and is substantiated the possibility of clarifying the categories of 'identity' and 'subjectivity' following the variability and uncertainty of the conditions of social reality. The research presents the idea of self-reference of identity (professional, transprofessional), which is considered through the characteristics of operations: self-determination, self-knowledge, self-creation, self-reproduction and selfrealization, with the help of which identity is distinguished and described. It is determined that self-reference as an operating system allows identity in the changed social reality to be self-fulfilling, bringing its meaning into one's own life. It is noted that transfessionalism is constructed following the actual life intentions of the individual and undergoes transformations synchronously with the latter. The practical value of scientific paper lies in the fact that the creation of a transfessional identity is a response to the request to enrich the individual with knowledge and technologies that go beyond the acquired profession and organically correlate with the individual's desire for self-realization.

Keywords: transprofessionalism, transfession, professional skills, qualification competencies.

Постановка проблеми. XXI століття справедливо означується як століття глобалізації, новітніх технологій та інновацій, століття нового мислення. Ознакою часу є динамічність глобальних змін, яка не може не позначитись на світовій системі освіти. Зокрема, тенденцію перемін помічаємо у тому, що 3 боку суспільства зростають вимоги до підготовки критично мислячої особистості, здатної до безперервного оновлення своїх знань, швидкого переучування, примінення своїх здібностей для успішного самоздійснення в мінливому світі. Певна річ, що в сучасному просторі високих технологій зростатиме як роль знань, так і вимоги до спеціалістів, які здатні розв'язувати комплексні проблеми. Тому освіту сприймаємо як відкриту i нелінійну розвивальну систему, суб'єкти якої реагують на динамічні зміни безперервним навчанням, в процесі якого постійно оновлюються їхні професійні 
компетентності, що уможливлюють успішне самоздійснення на межі різних професій. Вважається, що кар'єра будується на розвиткові професійного потенціалу і здатності до синтезу й конвергенції професійних компетенцій у різних сферах діяльності. У зв'язку із зазначеним у науковий дискурс входять поняття «транспрофесіоналізм», «трансфесіонал», «трансфесія».

Аналіз останніх досліджень i публікацій. Слід зазначити, що вищеназвані поняття безпосередньо стосуються питання зміни парадигми - від аналізу до синтезу на тлі інтеграції наук та стають предметом обговорення представників різних галузей знань, 3 різних методологічних позицій та культурних традицій. Логічно, що піднімаються питання співвіднесення міждисциплінарних, трансдисплінарних i конвергентних знань, де «міждисциплінарність і трансдициплінарність розглядаються як різні ступені конвергенції (синтезу, зближення) знань із різних наукових сфер. Зокрема, «міждисциплінарність - це синтез знань різних наукових дисциплін, але в межах однієї сфери - природничо-наукової чи соціогуманітарної; а трансдициплінарність - це конвергенція більш високого рівня. Вона передбачає взаємопроникнення знань різної «природи» - природничонаукової, соціогуманітарної, технічної» [1]. 3 цього розумісмо, що відбувається процес усвідомлення необхідності руху до трансдициплінарності, ідею якої озвучив філософ XX ст. Карл Раймонд Поппер у тезі про те, що жодну складну проблему неможливо розв'язати засобами тільки одної наукової дисципліни.

За матеріалами сучасних досліджень переосмислюється традиційна орієнтація освіти щодо «формування» конкурентно-спроможних фахівцівпрофесіоналів та порушується питання про зв'язок освіти 3 «трансфесією». Як метафорично пояснює Б. Ніколеску, «дисциплінарна, мультидисциплінарна, інтердисциплінарна і трансдисциплінарна стратегії подібні до чотирьох стріл, випущених з одного лука, ім'я якому знання» [2, С. 4]. 3 огляду на зазначене зупинимося на дотичній ідеї створювального потенціалу знання, зміст якої I. Доннікова та Н. Кривцова вбачають у набутті людиною навичок вчитися протягом усього життя, освоювати нові професії та види діяльності, тобто у трансфесіоналізмі. Дослідниці підкреслюють, що створювальність - це і характеристика власне знання (творчого, інноваційного за сутністю), і його функція (узгоджувана, синергійна) [3 ,С.33], що цілком узгоджується 3 думкою Дж. Кляйн, за якою «трансдисциплінарність дає змогу підвищити нереалізований інтелектуальний потенціал i, як наслідок, його ефективність» [4, С. 4].

Таким чином, на основі аналізу поглядів зарубіжних i вітчизняних дослідників на проблему трансдисциплінарності, що проявляється у синтезі знань природничих, соціально-гуманітарних, філософських, технічних наук, справедливо вважати трансдисциплінарність теоретичною основою транспрофесіоналізму (здатність розвивати професійний потенціал) та трансфесії (кваліфікаційна характеристика професійної діяльності). У цьому 
зв’язку інтерес представляють праці російських вчених (С. Галажинський, Є. Габітова, С. Зеєр, інші), які досліджують формування транспрофесіоналізму та трансфесіоналізму, перетворення професій в трансфесії та їхні сутнісні характеристики. Зокрема, поняття «трансфесія» як безперервний розвиток $\mathrm{i}$ перетворення особистості розглядається в порівнянні із поняттям «професія», що тлумачиться як орієнтування на досвід і набуття конкретних професійних якостей [5, С.11-17]. А. М. Уайтхед розглядає трансфесію як відкриту мережеву структуру, яка у індивіда формує здатності діяти над професійними границями і змінювати професію разом з собою [6, С. 56-71]. Є.Ф. Зеєр описує термін «трансфесія» як вид трудової активності, що реалізується на основі синтезу i конвергенції професійних компетенцій, які належать різним спеціалізованим галузям [7, C.9-28]. Тематичним ядром трансфесій дослідники вважають трансфесіоналізм, що тлумачиться як здатність до виконання широкого радіусу спеціалізованих видів діяльності і здібність в ситуації глобальної невизначеності знаходити власну траєкторію розвитку й керувати нею. С. Зеєр під трансфесіоналізмом розуміє якісну характеристику спеціаліста, що відтворює його готовність опановувати i виконувати дії, діяльність 3 функціонально близьких професій, що мають спільні об'єкти праці. Зокрема, Є. Галажинський відмічає, що трансфесіоналізм - це здатність особистості знаходити проблему і бачити системні способи їі вирішення в ситуації глобальної невизначеності, самостійно знаходити траєкторії розвитку для цього [7, С.13]. Відтак, натомість поняття «професія» в умовах мінливості і невизначеності соціальної реальності активується термін «трансфесія» як вид трудової активності, що реалізується на основі синтезу і взаємопроникнення професійних компетенцій, які належать різним спеціалізованим галузям.

Визначаючи особливості розглянутих категорій, дослідники також звертають увагу на поняття «професійна багатомірність», під якою розуміють здатність спеціаліста комбінувати, інтегрувати, виконувати одночасно декілька видів діяльності, володіючи при цьому багатомірними компетенціями: багатозадачність, поліфункціональність, мобільність, комунікабельність, тощо [8, С.326-330].

Беручи до уваги зазначені вище результати теоретичного аналізу досліджуваних понять, підсумовуємо, що трансфесіоналізм характеризується як властивість особистості розвивати свої професійні здатності. В умовах глобальних соціально-економічних змін трансфесіонал свідомо освоює інформацію з інших галузей знань, знаходить міжпредметні зв'язки, розширює професійні навички, набуваючи різні кваліфікаційні компетентності: хард-, софт-, діджітал-скіллз, щоби ефективно вибудовувати траєкторію свого само здійснення та успішно трансформувати свою професійну діяльність чи змінювати іiї спрямованість.

Цілком зрозумілою $\mathrm{i}$ прийнятною $\epsilon$ думка авторів монографії «Транспрофесіоналізм суб'єктів соціально-професійної діяльності» [9, С.14], які справедливо вважають, що в сучасних умовах соціальності функціональне 
коло обов'язків практично всіх робітників розширюється і виходить за рамки засвоєної конкретної професійної діяльності. Це призводить до того, що людині необхідно виконувати функції суміжних професій і тісно спілкуватися 3 колегами із різних галузей. Відповідно, сучасний ринок праці потребує від спеціалістів нових компетенцій, пов'язаних із розумінням необхідного інтелектуального забезпечення власної діяльності, відбором і використанням потрібних для цього знань та інших інтелектуальних засобів. Тлумачення трансфесіоналізму уточнюється переліком індикаторів: здатність до научіння (дозволяє отримувати необхідну інформацію з різних джерел, опрацьовувати iii, орієнтуватися в зростаючому обсязі інформації); суб'єктність того, хто навчається (здатність самостійно формувати свою освітню траєкторію у відповідності з власною структурою особистості); мобільність спеціаліста і його здатність функціонувати на межі різних професій.

Особливого значення при цьому, як стверджує Н. Кривцова, набуває зрілість особистості дослідника інформаційних ресурсів, яка не тільки забезпечує можливості перетворення «інформаційного хаосу» на джерело потенціалу самореалізації особистості трансфесіонала, а й знижуючи інформаційну ентропію зберегтися від особистісно-професійних деформацій та зміцнити здоров'я. Дослідниця резюмує, що компетентність у часі, цілісність сприйняття світу і себе в ньому, прагнення освіченої людини активно досліджувати складність мінливого світу та водночас розвинене критичне мислення, здатність до свідомого продуктивного самозмінювання в мінливих умовах зі збереженням автентичності власного життя і готовність дослідника інформаційних ресурсів до сизигії (поєднання) з Всесвітом на різних рівнях (природньому, соціальному, культурному та при організації власного життя в цілому) підвищують ймовірність нормотворчої самореалізації особистості трансфесіонала [10].

Таким чином, в умовах мінливості і невизначеності нашого часу спеціалісту вже недостатньо бути просто професіоналом 3 набутими професійними компетентностями, він має володіти - транспрофесіоналізмом. Це, на думку дослідників, не заперечує значущості базової професії, а сприяє виходу за її межі, збагачуючи їі знаннями, компетенціями і технологіями, що відносяться до інших видів професійної діяльності [11, С. 14].

Мета статті. Метою даної статті $\epsilon$ аналіз змісту i значення конструювання ідентичності трансфесіонала в процесі самореференції особистості.

Виклад основного матеріалу. Попри значний рівень досліджень ідентичності у часовому проміжку глибина цієї категорії все ж залишає можливості іï уточнення в науково-прикладних дослідженнях. Тлумачення ідентичності переглядається дослідниками у зв'язку із невідповідністю класично-традиційного уявлення про неї як про стабільне цілісне ядро особистості, що в сучасному світі стає досягненням не свідомості, а стосунків та утворюється на основі ситуативно обумовленого комунікативного досвіду. 
Журнал«Герспективитаіновації наукиљ

(Серія«Гедагогіка», Серія«Гтихологія», Серія«Медицинв»

№1(6) 2022

У відповідності до умов соціальної реальності, що означується як перехід до постнекласичного типу раціональності, науковий інтерес до проблеми ідентичності є реакцією на перебіг процесів глобалізації і поштовхом для їх теоретичного осмислення. Актуальність вивчення, передусім, пояснюється впливом наслідків соціальної трансформації та ситуації невизначеності на осмислення особистістю процесів самовизначення та самоздійснення. У відповідь на глобалізаційні соціокультурні виклики використовується конструкт «ідентичність у невизначеності». Запропоноване поняття як означення умов, в яких відбуваються процеси самоідентифікації особистості, на наш погляд, дозволяє розширити наукові дискусії у тій частині, що стосується пошуку себе, усвідомлення себе як суб'єкта своїх дій і означуванні ідентичності трансфесіонала в процесі самореференції особистості в професійних практиках.

Зауважуючи на тому, що ідентичність особистості визначається динамічними i змістовими (конкретні цілі, цінності, установки) характеристиками, суб'єктність особистості проявляється в здатності знаходити нові напрямки саморозвитку, володіти більшим потенціалом саморегулювання і більш зрілими механізмами соціального функціонування.

Зауважимо, що в умовах соціальної реальності ідентичність є темою постнекласичних досліджень в руслі конструктивістського напряму, де розглядається як сфера соціального пізнання (Ф. Барт, П. Бергер, Т. Лукман, інші). Проблематизація ідентичності, вочевидь, пов'язана 3 тим, що в процесі глобалізації та інформатизації людина не просто набуває більшої свободи вибору, вона все більше усвідомлює свою власну своєрідність. Цей контекст дозволяє вважати, що створюючи сучасну реальність, особистість вписується в неї, зумовлюється нею і представляє свою здатність бути різною й водночас залишатися собою. Покликаючись на висловлення 3. Баумана, «ідентичність стає призмою, через яку розглядаються, оцінюються і вивчаються чимало важливих рис сучасного життя» [12]. У розумінні дослідників П. Бергера i Т. Лукмана, «...ідентичність як елемент суб'єктивної реальності знаходиться у динамічному взаємозв'язку зі станом суспільства, вона формується у процесі засвоєння індивідом соціального світу, що одночасно проявляє себе в ньому і засвоює цей світ в якості значимої реальності [13] та самовизначається i самоздійснюється в соціальних практиках.

За Н. Луманом [14], суб'єкти як самореферентні системи здатні до розрізнення і означування себе тільки в оточуючому середовищі і тільки по відношенню до нього, тобто відповідно до дій, діяльності, в які є залученою. Саморозрізнення ідентичності (професійної, транспрофесійної) дозволяє суб'єкту визначитись у тому, що є його потребою і має сенс в актуальній комунікативній ситуації.

Процес самореференції ми розглядаємо через операції: самовизначення, самопізнання, самотворення, самовідтворення та самоздійснення, за допомогою яких відбувається розрізнення та описування ідентичності. 
Суттєво, що творячи самоопис, самореферентна ідентичність описує і смисл соціальної практики, в якій самоздійснюється.

Розкриємо зміст операцій процесу самореференції ідентичності.

1. Самовизначення - встановлення свого відношення до прийняття/заперечення, ідентифікації/відчуження цінностей, норм, правил, традицій, стереотипів, ролей, тощо. Відомо, що культура будь-якого історичного періоду як набір дискурсів дозволяє суб'єктивності знаходитися в межах певної історичної свідомості, що й визначає межі інтерпретації іiі індивідуальної свідомості. Суб'єктивність обумовлена характером комунікацій 3 Іншим/Іншими і будується в їх тісній взаємодії, що пояснює співіснування множини нетотожних смислів, по відношенню до яких особистість визначає індивідуальні цінності й конструює свою ідентичність. Особливість операції самовизначення бачимо у тому, що вона відбувається в ситуації невизначеності, розмитості, в яких суб'єктивність як властивість свідомості і фактор людської ідентичності сприймає світ у його плюральності. Операція самовизначення регулюється змістом власних переживань і пов'язана із розумінням себе відносно виконуваної дії, діяльності. Самовизначення ідентичності можна пояснити, скориставшись розумінням причини утворення ідентичності, яку пропонує С. Холл: нові ідентичності залежать від того, чого ми прагнемо і куди рухаємося. У даному контексті звернемо увагу на те, що самовизначення передбачає відповідальність особистості за здійснений вибір. Відтак, самовизначення ідентичності трансфесіонала результується конструюванням цілі професійної діяльності, смислом научування/переучування та проявляється у трансфесії на основі синтезу i взаємопроникнення професійних компетенцій із різних галузей.

2. Самопізнання - операція, завдячуючи якій ідентичність набуває особливого сприйняття - постмодерністської чутливості. В даному контексті постмодерністська чутливість (М. Хайдеггер) тлумачиться як сприйняття світу, коли мова йде не стільки про світогляд, скільки про світовідчуття, про глибоко емоційну, внутрішньо відчуту, прожиту реакцію на оточуючий фрагментарний світ із його локальними ситуаціями. На думку О. Кочубейник, це означає, що постмодерністська чутливість перетворюється на головний інструмент пізнання, який дозволяє виявити й зафіксувати різноманіття індивідуального життєвого досвіду й соціального світу, а тому усі процедури отримання й інтерпретації даних спрямовані на те, щоб «вхопити, як саме окрема особа через своє унікальне суб'єктивне розуміння навколишнього соціального світу транслює й формує інтерсуб'єктивні смисли» [15]. Отже, операція самопізнання артикульована на почування змісту пережитого досвіду, зокрема, професійного, несе суб'єктивне значення для означування себе у різних соціальних практиках.

Поряд із зміною образу мислення змінюється й ускладнюється суб'єктивність. Через це вона ніби виходить за межі самої себе, що дозволяє людині розширити границі професійної ідентичності, яка пізнається в 
діяльності, існує в ній i впливає на здатність змінюватися відносно актуальності своїх потреб, почувань, бажань, ін.

3. Операція самотворення. У доробку М. Боришевського самотворення визначено як процес вибудовування себе, своєї самості задля досягнення згоди iз собою з метою збереження ідентичності як активного суб'єкта самотворення з відносно високим рівнем розвитку [16]. Коментуючи цю думку, Л. Сердюк зазначає, що вчений розглядав самотворення як онтологічну категорію, у контексті котрої усвідомлюються альтернативи та перспективи збереження i розвитку буття людини як вищої істоти, а умовою чи принципом самотворення виступає духовність особистості як основа для іiі сходження до найвищих ціннісних інстанцій [17]. 3 цієї позиції самотворення представлено як самосуб'єктна активність особистості, яка передбачає відносно високий рівень iii розвитку, зокрема вагому представленість у іiі структурі таких утворень, як моральні переконання, сформованість світоглядних позицій та інші орієнтації - складники системи духовності, наявність структурованої Я-концепції, розвиненість системи саморегуляції та деяких компонентів, що засвідчують достатньо високий рівень розвитку особистості як відкритої соціальнопсихологічної системи, яка перебуває у стані постійного саморозвитку [17].

Отже, самотворення ідентичності трансфесіонала в умовах невизначеності соціальної реальності $€$ відповіддю на виклики ситуацій, відносно яких особистість саморозвивається i розкриває свою індивідуальність.

4. Самовідтворення - операція з відновлення ідентичності, включеної у соціально-психологічні практики. Позаяк ідентичність $є$ дискурсивною за своєю природою, то самовідтворення слугує для того, щоби у відповідь на виклики глобалізованого світу відновити/реконструювати ідентичність, яка 3 певних причин втратила свою значущість. Як відмічає Л. Орбан-Лембрик, нестабільність розвитку суспільства й індивідуальні особливості розвитку людей створюють різноманітні лінії соціальної поведінки і варіанти їхнього життєвого шляху [18]. Це забезпечує можливість пошуку себе у стосунках 3 іншими людьми, зі світом речей, що постійно змінюються. На цю особливість вказує i Т. Титаренко, коли характеризує постнекласичну особистість. На думку науковця, особистість постійно перебуває у процесі становлення, у стані переходу від актуального до потенційного буття. Вона є органічною часткою як соціального, так i приватного життя, специфічною соціальнопсихологічною конструкцією, вплетеною у повсякдення. На кожному етапі життя вона стає результатом самоконструювання, що відбувається на тлі відповідних історико-культурних та інших процесів [19]. У даному контексті визначено, що суттєвою ознакою особистості $є$ те, що вона «прислухається до власної своєрідності, втрачаючи колишню лінійну детермінованість, жорстку визначеність, одноголосся за рахунок практично безмежної відкритості, поліфонічності, здатності до змін i навичок захисту свого права бути інакшою [19]. 
5. Самоздійснення - операція здійснення цільових поведінкових актів, дій, діяльності, в яких самореферентна ідентичність розрізнює й описує себе. Важливо наголосити на істотному значенні власних відчуттів, почувань, думок, значень, що уможливлюють розуміння себе. Кожна людина створює власний дизайн свого життя, і конструювання ідентичності трансфесіонала позначається на його способі життя в соціумі. Зауважимо, що наповнена індивідуальним смислом існування, ідентичність переживається i проживається не тільки як суб’єктивний феномен, а як об’єктивна складова сучасного світу.

Відтак, самореференція як операціональна система дозволяє ідентичності у зміненій соціальній реальності самоздійснитись, вносячи свій смисл у власне життя, який розуміється не як іманентний об'єкту, а як результат довільно конструйованих соціальних практик, в яких особистість шукає відповіді на виклики часу. Дозволимо припустити, що трансфесіональність конструюється відповідно до актуальних життєвих інтенцій особистості й зазнає трансформацій синхронно до останніх. Таким чином, будь-яка смислова інтенція стає пусковою для процесу самореференції ідентичності трансфесіонала. Як метафорично зауважує О. Кочубейник, світ в собі і світ навколо себе людина перетворює у світ для себе [15].

Висновки. Таким чином, здійснений аналіз дозволяє зрозуміти зміст конструювання ідентичності трансфесіонала в процесі самореференції особистості в професійних практиках. Значення творення ідентичності трансфесіонала бачимо у тому, що у відповідь на мінливість і динамічність соціальної реальності є запит на збагачення особистості знаннями і технологіями з різних професійних галузей, що закономірно розширює межі професійної діяльності, та не знижує потреби у самоздійсненні. Адже успішність кар'єрного зростання залежить від здатності особистості синтезувати професійні компетентності, які формуються в різних сферах діяльності, тобто грунтуються на транспрофесіоналізмі. Разом 3 цим соціальний запит на компетентних, умотивованих, кваліфікованих спеціалістів, які самостійно і творчо здобувають інформацію, гнучкі до переучування і готові професійно розвиватися впродовж життя, можуть реалізувати особистості, які чітко означують свою ідентичність. Найкращими транс професіоналами вважаються спеціалісти, що мають грунтовні базові знання з обраного фаху, та продовжують збагачуватись новими знаннями, що виходять за межі набутої професії, відкрити в своїй професійній діяльності до формування нових компетентностей і вдосконалення наявних. До прикладу, спеціаліст, який засвоїв одну професію, за необхідності переходить іiі межу, переносячи набуті знання, технологіi, уміння, навички в іншу сферу, що у підсумку породжує нові міждисциплінарні і трансдисциплінарні знання, технології, уміння, навички. Отже, ідентичність транспрофесіонала проявляється в потребі вчитися протягом усього життя, освоювати нові професії та види діяльності, що органічно співвідносяться із прагненням до самоздійснення. 


\section{Лimepamypa:}

1. Галажинский Э. Слово - ректору. О трансфессии и трансдисциплинарности. В 2 ч. URL: http://www.tsu.ru/university/rector_page/o-transfessii-itransditsiplinarnosti-chast-2/

2. Nicolescu B. The transdisciplinary evolution of learning / Basarab Nicolescu. - Режим доступу: http://www.learndev.org/dl/nicolescu_f.pdf

3. Доннікова I., Кривцова Н.Створювальне знання в мультидисциплінарному освітньому контексті. Вісник Львівського університету. Серія філос.-політолог. студії. 2019. Випуск 26, с. 32-39 Visnuk of the Lviv University. Series Philos.-Political Studies. Issue 26, p. 32-39 DOI https://doi.org/10.30970/2307-1664.2019.26.4

4. Klein J. Th. Transdisciplinarity: Joint Problem Solving Among Science, Technology, and Society: An Effective Way for Managing Complexity / Julie Thompson Klein. - Birkhäuser, 2001. $-332 \mathrm{p}$.

5. Александрова Т.Л. Методологические проблемы социологии профессий // Социологические исследования. 2000. № 8. С. 11-17.

6. Уайтхед А.Н. Наука и современный мир // Избранные работы по философии. Москва, 2000. С. 56-71.

7. Зеер Э.Ф., Сыманюк Э.Э. Методологические ориентиры развития транспрофессионализма педагогов профессионального образования // Образование и наука. 2017. № 8. С. 9-28.

8. Ялалов Ф. Г. Профессиональная многомерность: многомерные компетенции // Филология и наука. 2015. № 2 (40). С. 326-330.

9. Зеер Э.Ф. Заводчиков Д.П. Зиннатова М. В., Третьякова В.С. Транспрофессионализм субъектов социально-профессиональной деятельности: монография. Екатеринбург: Изд-во Рос. гос. проф.-пед. ун-та, 2019. 142 с. [Электронный ресурс]. Режим доступа: http://elar.rsvpu.ru/978-5-8050-0668-6.pdf, C. 14.

10. Кривцова Н.В. Шлях до гармонії життя: теорія і практика самореалізації: монографія / Н.В. Кривцова. Харків: Факт, 2019. 404 с.

11. Зеер Э. Ф. Методологические ориентиры развития транспрофессионализма педагогов профессионального образования / Э.Ф. Зеер, Э. Э. Сыманюк // Образование и наука. 2017. Том 19. № 8. С. 9-28.

12. Бауман 3. Индивидуализированное общество / Зигмунт Бауман / Пер. с англ. под ред. В.Л. Иноземцева. - М: Логос, 2005. 390 с.

13. Бергер П., Лукман Т. Социальное конструирование реальности. Трактат по социологии знания / Питер Бергер, Томас Лукман; пер. с англ.. Е. Руткевич. - М.: «Медиум» 1995. $323 \mathrm{c}$.

14. Луман Н. Самоописания. Пер. с нем. А. Антоновский, Б. Скуратов, К.Тимофеева. - М. Издательство “ Логос”, ИТДГК “Гнозис”. 2009. 320 с.

15. Кочубейник О. М. Постмодерн: автентичність особистості та трансформація дискурсу соціальності/ Qльга Миколаївна Кочубейник // Вісник Національного технічного університету України «Київський політехнічний інститут». Філософія. Психологія. Педагогіка. Зб. наук. праць. - Київ: ІВЦ «Політехніка», 2010. - № 1(28). С.113-118.

16. Боришевський М. Концептуальні засади проблеми самотворення особистості / Мирослав Боришевський // Психологія особистості. 2013. - №1. С. 39- 47.

17. Сердюк Л. 3. Самотворення особистості як цілісний самодетермінований феномен / Людмила Захарівна Сердюк // Актуальні проблеми психологї . 2015. - Т.7, Вип. 38. С. $422-431$.

18. Орбан-Лембрик Л. Е. Соціальна психологія. Посібник / Лідія Ернестівна ОрбанЛембрик - К.: Академвидав, 2003. 448 с.

19. Титаренко, Т. М. Життєвий світ особистості у межах і за межами буденності / Тетяна Михайлівна Титаренко - К. Либідь, 2003. 376 с. 


\section{References:}

1. Galazhinskij, Je. Slovo - rektoru. O transfessii i transdisciplinarnosti [A word to the rector. About transfusion and transdisciplinarity]. www.tsu.ru. Retrieved from http://www.tsu.ru/university/rector_page/o-transfessii-itransditsiplinarnosti-chast-2/[in Ukrainian].

2. Nicolescu B. The transdisciplinary evolution of learning / Basarab Nicolescu. - Режим доступу: http://www.learndev.org/dl/nicolescu_f.pdf

3. Donnikova, I., Krivcova, N. (2019). Stvorjuval'ne znannja v mul'tidisciplinarnomu osvitn'omu konteksti [Creative knowledge in a multidisciplinary educational context]. Visnik L'vivs'kogo universitetu. Serija filos.-politolog. studii - Bulletin of Lviv University. Series philosopher-political scientist, 26, 32-39 [in Ukrainian].

4. Klein J. Th. Transdisciplinarity: Joint Problem Solving Among Science, Technology, and Society: An Effective Way for Managing Complexity / Julie Thompson Klein. - Birkhäuser, 2001. $-332 \mathrm{p}$.

5. Aleksandrova, T.L. (2000). Metodologicheskie problemy sociologii professij [Methodological problems of sociology of professions]. Sociologicheskie issledovanija Sociological research, 8, 11-17 [in Russian].

6. Uajthed, A.N. (2000). Nauka i sovremennyj mir [Science and the modern world]. Izbrannye raboty po filosofii - Selected works on philosophy, 56-71 [in Russian].

7. Zeer, Je.F., Symanjuk, Je.Je. (2017). Metodologicheskie orientiry razvitija transprofessionalizma pedagogov professional'nogo obrazovanija [Methodological guidelines for the development of transprofessionalism of teachers of vocational education]. Obrazovanie $i$ nauka - Education and Science, 8, 9-28 [in Russian].

8. Jalalov, F. G. (2015). Professional'naja mnogomernost': mnogomernye kompetencii [Professional multidimensionality: multidimensional competencies]. Filologija i nauka- Philology and Science, 2 (40), 326-330 [in Russian].

9. Zeer, Je.F. Zavodchikov, D.P. Zinnatova, M. V., Tret'jakova, V.S. (2019). Transprofessionalizm sub\#ektov social'no-professional'noj dejatel'nosti [Transprofessionalism of subjects of social and professional activity]. Ekaterinburg: Izd-vo Ros. gos. prof.-ped. un-ta [in Russian].

10. Krivcova, N.V. (2019). Shljah do garmoniï zhittja: teorija i praktika samorealizacii [The way to the harmony of life: theory and practice of self-realization]. Harkiv: Fakt [in Ukrainian].

11. Zeer, Je. F. (2017). Metodologicheskie orientiry razvitija transprofessionalizma pedagogov professional'nogo obrazovanija [Methodological guidelines for the development of transprofessionalism of teachers of professional educatio]. Obrazovanie i nauka-Education and Science, 19, 8, 9-28 [in Ukrainian].

12. Bauman, Z. (2005). Individualizirovannoe obshhestvo [Individualized society]. M: Logos [in Russian].

13. Berger, P., Lukman, T. (1995). Social'noe konstruirovanie real'nosti. Traktat po sociologii znanija [Social construction of reality. Treatise on the Sociology of Knowledge]. M.: «Medium» [in Russian].

14. Luman, N. (2009). Samoopisanija [Self-descriptions]. M. Izdatel'stvo “ Logos”, ITDGK “Gnozis" [in Russian].

15. Kochubejnik, O. M. (2010). Postmodern: avtentichnist' osobistosti ta transformacija diskursu social'nosti[Postmodern: authenticity of personality and transformation of the discourse of sociality]. Visnik Nacional'nogo tehnichnogo universitetu Ukraïni «Kï̈vs'kij politehnichnij institut». Filosofija. Psihologija. Pedagogika. - Bulletin of the National Technical University of Ukraine "Kyiv Polytechnic Institute". Philosophy. Psychology. Pedagogy, 1(28), 113-118 [in Ukrainian].

16. Borishevs'kij, M. (2013). Konceptual'ni zasadi problemi samotvorennja osobistosti [Conceptual principles of the problem of self-creation of personality]. Psihologija osobistosti Psychology of personality, 1, 39-47 [in Ukrainian]. 
17. Cerdjuk, L. Z. (2015). Samotvorennja osobistosti jak cilisnij samodeterminovanij fenomen [Self-creation of personality as a holistic self-determined phenomenon]. Aktual'ni problemi psihologii - Actual problems of psychology, 7, 38, 422-431 [in Ukrainian].

18. Orban-Lembrik, L. E. (2003). Social'na psihologija [Social Psychology]. K.: Akademvidav [in Ukrainian].

19. Titarenko, T. M. (2003). Zhittevij svit osobistosti u mezhah i za mezhami budennosti [Life world of the individual within and beyond everyday life]. K. Libid' [in Ukrainian]. 